\title{
The Role of Public-Sector Unions During Privatization
}

\author{
Jungin Kim*
}

\begin{abstract}
This paper reviews the historical and institutional backgrounds of public- and private-sector unions, internal and external trends involving publicsector unions, union representation in the public sector, union affiliation with citizens, and the relationship between privatization and public unions. Using these characteristics to reflect on the fundamental rationale of public-sector unions as the negotiators for public employees and as the promoters of political affiliation with citizens, the nature of the labor-management relationship emerges as a key factor in determining the effectiveness of unions in these roles.
\end{abstract}

Keywords: public-sector unions, privatization, representative power

\section{INTRODUCTION}

According to the Department of Labor (2007), the union membership rate for government workers was five times higher than for private industry workers in 2006. Unionization is not the private sector's exclusive domain any more. Since the 1930s, American union membership in the private sector has fallen to less than 9 percent, and private-sector employee strike activity has almost faded away. In contrast, public-sector unions have shown robust growth rates as wages and working conditions are set through negotiations with elected local and state officials (Nigro, Nigro, and Kellough 2007). This trend might mean that public-sector unions are becoming stronger and more stable than private-sector unions (Hurd and Pinnock 2004).

The avalanche of public-sector unionization and collective bargaining in the 1960s and 1970s (Reeves 2005) brought public managers to the bargaining table for employee pay raises, improved benefits, better working conditions, and the right to participate in the making of personnel policies (Nigro, Nigro, and Kellough 2007; Kettle and Fesler

\footnotetext{
* Jungin Kim is a senior researcher at the Korea Human Resources Research Center. Her research interests include human resources policy, affirmative action, civil service reform, and equal employment opportunities. E-mail: jungink@gmail.com.
}

Manuscript received September 2, 2010; out for review October 21, 2010; review completed November 16, 2010; accepted December 7, 2010.

The Korean Journal of Policy Studies, Vol. 25, No. 3 (2010), pp. 23-45.

(C) 2010 by the GSPA, Seoul National University 
2005). ${ }^{1}$ In terms of government service delivery, issues of public-sector labor relations have been dealt with primarily in order to provide high-quality public services to the citizens. Furthermore, lack of market competition for the products of the public sector and lack of fiscal discipline through the political process make the value of unions to public-sector employees relatively high (Farber 2005).

Recently, however, public-sector unions have faced threats from massive budget deficits and privatization just as private sector unions have been challenged by globalization, deregulation, and increased management hostility (Hurd 2003). Public-sector employees and unions are at risk of privatization, fiscal limits, civil service reform, pension reform, and the rollback of collective bargaining rights due to changes in the political, economic, and social environment (McEntee 2006). Public-sector unions need to cope successfully with these challenges in order to survive.

Public-sector unions continue to face challenges in Korea as well. As a key player in labor-management relationships, public-sector unions can help promote a good organizational culture that pursues productivity improvement and other goals effectively and efficiently in the public sector. However, there is little research about public unions in Korea. By exploring the experience of public unions in other countries, especially the United States, Korean public unions may find the clear reasons why they need to be existed.

This study examines public-sector unions' historical and institutional backgrounds and changing trends in comparison to private-sector unions through an extensive and in-depth examination of previous studies on the issue. It reviews union representation in the public-sector workforce and unions' affiliation with citizens. It examines whether recent privatization trends affect the extent to which public-sector unions can promote public employees' interests in terms of bargaining power and rights and the extent to which union political activities are associated with citizens as well as public employees.

1. In 2006, the union membership rate for government workers was 36.2 percent, and the rate for workers in private industry was 7.4 percent. Within the public sector, local government workers had the highest union membership rate, 41.9 percent. This group includes several heavily unionized occupations, such as teachers, police officers, and firefighters. Among major private industries, transportation and utilities had the highest union membership rate at 23.2 percent, followed by construction at 13.0 percent. 


\section{PUBLIC-SECTOR UNION CHARACTERISTICS}

\section{Historical and Institutional Characteristics of Public- and Private-Sector Unions}

To understand the role of public-sector unions, it is important to understand their historical and institutional background and compare it to that of private-sector unions. The earliest organizing efforts in the United States were by craft unions which are labor unions with membership limited to workers in the same craft. The Knights of Labor, which was formed in Philadelphia in 1869, made the first significant unionization effort, and by 1878 it had evolved into the first national labor union in the United States (Kearney and Carnevale 2001). In 1881, the American Federation of Labor (AFL) was formed in Pittsburgh and grew steadily. However, it did not allow nonskilled, noncraft workers into the organization, and John L. Lewis of the United Mine Workers formed the Congress of Industrial Organizations (CIO) ${ }^{2}$ as an attempt to gain affiliation for industrial workers. In 1955, after years of conflict and competition, the AFL merged with the CIO; this merger marked the beginning of a long and continuous decline in private-sector union organization (Kearney and Carnevale 2001).

Regarding private-sector unionization, the National Labor Relations Act of 1935 and its amendments provide the basis for procedures and policies set forth by the National Labor Relations Board (Nigro, Nigro, and Kellough 2007). While the rights of employees to bargain collectively through their representatives was generally accepted in the private sector after 1935, federal employees were denied access to parallel arrangements for settling labor-management conflicts and had to rely upon political action to advance their goals. Operating in a unique labor market with entrance requirements, work rules, and job rights that differed from those prevailing in the private sector, the emerging federal unions were forced to "bargain" with Congress to achieve ends that private-sector unions gained at the bargaining table (Levitan and Noden 1983).

This restriction, which lasted until the 1960s, was mainly based on the sovereignty doctrine (Kearney and Carnevale 2001). As the "sovereign employer," the government had the power to fix through law the terms and conditions of government work, including organizational membership. This power could not be given away or shared through negotiations with a public employee organization (Nigro 1968; Kearney and Carnevale 2001).

The sovereignty doctrine was weakened through the social and political turbulence

2. It was originally named the Committee for Industrial Organization. 
of the 1960s, and collective bargaining, a bilateral decision-making process conducted by authorized representatives of management and labor, spread rapidly in the public sector (Nigro, Nigro, and Kellough 2007). According to Nigro, Nigro, and Kellough (2007), good faith negotiation of wages, hours, and working conditions; a mutually binding written contract of specified duration; and agreement to share responsibility for administering the provisions of that contract are the main concerns of collective bargaining. Since collective bargaining determines many terms of the employment relationship through bilateral negotiation, including "demonstrable just cause," it stands in stark contrast to the traditional merit system (Nigro, Nigro, and Kellough 2007; Reeves 2005; Camp and Lomax 1968).

Collective bargaining is governed by the 1935 National Labor Relations Act, also known as the Wagner Act. It defined and protected the rights of workers to organize into labor unions and to bargain collectively with their employers regarding the terms and conditions of employment (Farber 2005), but it primarily addressed the private sector. In 1948, this act was amended by the Taft-Hartley Act, which made it illegal for union contracts to include union security provisions. ${ }^{3}$ Farber's 2005 study revealed the effect of Taft-Hartley on private-sector unions, showing that the private-sector union membership rate was 3.8 percent in the 22 states with right-to-work laws that secure the right of employees to decide for themselves whether or not to join or financially support a union, versus 14.4 percent in states without right-to-work laws.

The legal environment for public-sector unions is more complex than for private sector unions, because in addition to routine management concerns such as budgeting, it is also governed by civil service and other laws controlling employment practices (Nigro 1968). The right to bargain collectively is effective only if unions have the ultimate weapon of the right to strike, but public-sector employees have had very different rules in this regard than those in the private sector, and some states prohibit employees from striking (Kettl and Fesler 2005, 185).

The legal basis of labor relations in federal employment is the Civil Service Reform Act of 1978, which was developed thorough executive orders such as President Kennedy's Executive Order 10988, President Nixon's Executive Order 11491, and President Clinton's Executive Order 12871. Collective bargaining by state and local government employees is governed by legislation passed at the state level (Farber

3. According to Farber (2005) and Freeman and Valletta (1988), union security provisions include "union shop" clauses, which require employees to become dues-paying members of the union within a fixed period of time after hiring, and "agency shop" clauses, which require employees to either become dues-paying members or pay a fee to the union in lieu of dues. 
2005); more than 110 separate state statutes determining public-sector labor relations existed in 2001 (Kearney and Carnevale 2001). According to Farber (2005), union coverage is significantly higher where unions are allowed to negotiate union security provisions and where labor unions have a legal duty to bargain with employers on behalf of employees.

\section{The Rise of Public-Sector Unions and the Fall of Private-Sector Unions}

While the union membership rate in the private sector fell from 25 percent in 1975 to 7.4 percent in 2006, the rate in the public sector increased from the same level in 1975 to over 36 percent in 2006 (Nigro, Nigro, and Kellough 2007; Farber 2005). In this regard, many scholars have tried to predict the future of public employee unions and to discover which public employees are joining unions and why (e.g., Nigro, Nigro, and Kellough 2007; Riccucci 2007; Reeves 2005; Farber 2005).

The different membership patterns for private- and public-sector unions are closely linked with broad social, global, demographic, and economic trends (Calo 2006). Factors that have influenced the decline in private-sector unionization include economic changes such as globalization (Riccucci 2007; Farber 2005), social changes such as employers' objection to unionism (Farber 2005), legal changes such as changes in the administration of the National Labor Relations Act due to changes in composition of the National Labor Relations Board (Levy 1985), and technological advances (Riccucci 2007). More importantly, increases in the female, minority, and part-time segments of the work force, as well as in the number of white-collar workers, have contributed to the decline (Kearney and Carnevale 2001; Lipset and Katchanovski 2001). ${ }^{4}$

Meanwhile, the steady rise in public-sector unions parallels the emergence of laws favorable to unions, increased bargaining power, organizing along the lines of craft unions, and increased psychological orientation to seeking representation for public employees' interests (Calo 2006; Guiler and Shafritz 2004). Unionism and the collective bargaining movement have dramatically increased in the public sector, and many union organizations have evolved, as shown in Table 1.

4. According to Kearney and Carnevale (2001), white-collar workers have historically been difficult to organize because of the prestige and professionalism associated with their jobs, special interests and needs that have not been attended to by the unions, and the generally poor image of organized labor among this group. 
Table 1. Union Representation, 1992-2006

\begin{tabular}{|c|c|c|c|c|c|c|c|}
\hline & & 1992 & 1996 & 2000 & 2004 & 2005 & 2006 \\
\hline \multicolumn{2}{|l|}{ Private sector* } & $12.7 \%$ & $11.2 \%$ & $9.8 \%$ & $8.6 \%$ & $8.5 \%$ & $8.1 \%$ \\
\hline \multirow{4}{*}{ Public sector } & Total & $43.2 \%$ & $43.0 \%$ & $42.0 \%$ & $40.7 \%$ & $40.5 \%$ & $40.1 \%$ \\
\hline & Federal & NA & $38.9 \%$ & $36.7 \%$ & $35.0 \%$ & $33.1 \%$ & $33.7 \%$ \\
\hline & State & NA & $35.3 \%$ & $34.2 \%$ & $34.3 \%$ & $35.0 \%$ & $33.6 \%$ \\
\hline & Local & NA & $48.4 \%$ & $47.9 \%$ & $45.8 \%$ & $45.8 \%$ & $45.7 \%$ \\
\hline
\end{tabular}

Source: U.S. Bureau of Labor Statistics (2007).

* total private sector including agriculture and nonagricultural industries

\section{Subsectors of Public-Sector Unionism}

Public employee unionism can be divided into three subsectors: federal, state, and local government employee unions (Farber 2005). Unions in these three subsectors have faced varied labor law environments and organizational characteristics.

At the federal level, Title VII of the Civil Service Reform Act established a system of labor relations in which the Federal Labor Relations Authority (FLRA) is responsible in terms of issuing policy related decisions and adjudicating disputes regarding labor-managementrelationship (Nigro, Nigro, and Kellough 2007; Reeves 2005). ${ }^{5}$ The evolution of federal labor-management relations and unionism was also affected by executive orders issued by presidents John F. Kennedy (1962), Richard Nixon (1969), and Gerald Ford (1976) (Riccucci 2006). Union membership rates among federal government workers were approximately 30 percent from 1983 to 2004 (Farber 2005), and presidents Ronald Reagan, George H. Bush, and Bill Clinton, whose measures (such as the National Partnership Council in 2000) were especially influential, attempted to improve the partnership between public employers and employee unions (Reeves 2005).

The largest union representing federal employees is the Metal Trades Council, which is made up of several national craft unions. Three other major federal unions are

5. Three units within the FLRA were responsible for mediating disputes, settling impasses, and prosecuting unfair practices: the Federal Service Impasses Panel, the Federal Mediation and Conciliation Service, and the General Counsel (Reeves 2005). Even though the LloydLaFollette Act of 1912, guaranteeing federal employees the First Amendment right to organize and petition Congress for a redress of grievances, had only a small effect on federal union-busting activities, it showed new direction in the development of postal and other federal labor organizations (Kearney and Carnevale 2001). 
the American Federation of Government Employees (founded in 1932 and representing almost 600,000 federal employees), the National Federation of Federal Employees (formed in 1917 and representing about 90,000 federal employees), and the National Treasury Employees Union (formed in 1938. and representing about 150,000 workers) (Nigro, Nigro, and Kellough 2007).

Union membership rates among state and local government employees are about 30 and 40 percent respectively (Farber 2005). In state and local governments, collective bargaining systems are based on statutes or ordinances, except in a few cases where they have been set up by executive orders, and they are usually administered by an agency, such New York State's Public Employment Relations Board and Ohio's State Employment Relation Board (Nigro, Nigro, and Kellough 2007).

In terms of state government unionism, state employee associations were created for purposes such as providing unified general representation for government employees and accomplishing economic objectives through traditional pluralistic processes (Nigro, Nigro, and Kellough 2007; Bent and Reeves 1978). Most of the state associations are affiliated with the Assembly of Government Employees, which was established in 1952 and supports merit systems over collective bargaining. However, other state associations like the California State Employees Association ${ }^{6}$ are affiliated with the American Federation of State, County, and Municipal Employees (AFSCME), which is the largest state and local union today (Kearney and Carnevale 2001), and with other AFL-CIO organizations in order to build their bargaining power and resources (Nigro, Nigro, and Kellough 2007).

In local government, a crafts orientation was clearly prevalent as teachers, firefighters, and police organized separately (Kearney and Carnevale 2001). The National Teachers Association was formed in 1857 and merged with two other teacher associations to form the National Education Association in 1870. The American Federation of Teachers, formed in 1916 by uniting other teacher organizations, represented roughly 67 percent of union members in 2003 (Riccucci 2007). Firefighters and police began organizing during the late 1800s and the early years of the 20th century, and in 1918 the AFL chartered the International Association of Fire Fighters, which currently represents about 267,000 professional firefighters and paramedics (Nigro, Nigro, and Kellough 2007; Kearney 2001).

6. The California State Employees Association was established during the early 1930s and is now a local chapter of the Service Employees International Union, which represents about 85,000 workers in 21 bargaining units (Nigro, Nigro, and Kellough 2007). 


\section{PUBLIC-SECTOR UNIONS AND PRIVATIZATION}

Simons (2002) examined AFSCME's role in the Temporary Assistance to Needy Families program and found that AFSCME and other public-sector unions have a distinct interest in future welfare policies and programs for public sector employees and are deeply involved in debate on policies affecting public sector employees' welfare by representing employees' rights and needs.

For better understanding of public-sector unions, it is necessary to consider how they have evolved, whose interests they most represent when compared to private-sector unions, and whether their sole obligation is to protect employees' interests, as is the case for private-sector unions. These questions have recently become particularly relevant as public sector organizations are pressured by stakeholders to adopt various market-oriented polices: privatization, reinventing government, and no government intervention (Hurd and Bunge 2003). In addition, the adoption of at-will employment (in which an employer can fire employees without a reason), which has been expanded to many public-sector organizations in the United States, is likely to be influenced by stakeholders, especially public-sector unions (Kellough and Selden 2003). Some previous research (e.g., Coggburn 2000, 2001) found that public-sector unions influenced the adoption of at-will employment, and most were not favorable to this approach. Through such environmental challenges, a paradigm shift in public-sector union identification has occurred (Calo 2006).

\section{Theories that Help Explain Public-Sector Union Issues}

In order to answer the questions noted above, and in order to analyze the needs of public-sector unions, three major conceptual theories need to be reviewed: rational choice, social identity, and attribution (Reshef 2001). ${ }^{7}$ Rational choice theory, based on Olson's (1971) theory of collective action, illustrates why public-sector unions represent their members' interests. Individuals depend on rational thoughts to judge the potential costs and benefits of their decisions, such as whether to participate in collective actions. In this regard, public-sector unions must be instrumental and competitively institutionalized for public employees to achieve their goals at work in order to attract membership (Klandermans 1986).

7. Most previous research (e.g., Klandermans 1986; Frege 1996) presented four theories to explain individuals' participation in collective action: rational choice, social identity, attribution, and frustration-aggression. However, the present study does not include the theory of frustration-aggression because it focuses only on striving for system equilibrium. 
The concept of social identity, which is defined as the "embeddedness of individuals in social groups and the influence on their behavior of intergroup relations" (Frege 1996, 391), can be used to explore unions' roles and needs. Social identity includes intragroup identification and intergroup differentiation (Kelly 1993), which describes the dynamics of labor-management relationships. Therefore, to understand why public-sector unions represent the interests of their members, social identity theory needs to be explained.

Attribution theory is useful for understanding why public-sector unions may not always be representative of public employees. It relates the behavior of individuals, such as public-sector union representatives, to larger social environments (Frege 1996; Weiner 1985). Together, these theories provide a useful foundation for the following discussion of union representation and of why public-sector unions need to be considered as a policy factor.

\section{Union Representation in the Public-Sector Workforce}

The principle of exclusive representation appears in Sec. 9(a) of the National Labor Relations Act of 1935. This clause says that if a majority of employees of a particular firm vote to be represented by a particular union, that union is then the sole representative of all workers, whether an individual worker voted for or against it or did not vote at all. That is, individual workers are not free to designate representatives of their own choosing (Boaz and Crane 2003). Even though the open shop arrangement, which employees are not required to join or support a union for the condition of hiring or employment, raises a "free riders" issue that might weaken unions' financial positions and also their bargaining power (Nigro, Nigro, and Kellough 2007), exclusive bargaining agents employing union shop or agency shop based on the National Labor Relations Act are not likely to represent the general interests of all labor (Boaz and Crane 2003). ${ }^{8}$ In other words, forced unionism rather than voluntary unionism may not represent all employees.

Despite the limitations of forced unionism, however, the labor union provides employees with a democratic vehicle for representation and articulation of their interests. The contract between the union and the employer, which covers the employees' legal rights in their jobs, wages, and working conditions, provides employees with a bill of rights (Zander 1962). In particular, previous research has shown that employees

8. According to Boaz and Crane (2003), the National Labor Relations Act neglects one of the most important privileges of U.S. citizens - the right of each individual worker to enter into hiring contracts with willing employers on terms that are mutually acceptable. 
rely on unions as a means of resolving their dissatisfaction with their jobs (Kochan 1979).

Compared to collective bargaining in private employment, which involves private decision-making shaped by market forces, public-sector labor relations involve an explicit political dimension, in which political forces shape government decision-making (Summers 1974; Sulzner 1985; Bennett and Taylor 2001). Therefore, in contrast to mainstream practices in industry, public-sector unions attempt to influence policymaking through efforts such as coordinated joint lobbying. Traditionally, public-sector unions at all governmental levels have used their political power to check or overrule administrations and to obtain legislation spelling out standards for working conditions in detail (Spero 1962). For instance, unions may seek out the views of legislators or political candidates toward pending legislation affecting public employees and then publicize the answers to generate public support for their cause (Zander 1962).

For a long time, the public sector debated questions of whether, and under what restrictions and conditions, the institution of collective bargaining should be imported into the public sector. More specifically, the New Public Management and New Public Service movement during the last two decades has emphasized efficient and effective public service delivery through decentralization and privatization (Gahan 2007). Meanwhile, the increasing concerns about discretion for employee management and labor-management relationships, the scope and discretion of bargaining, and related rules and regulations also became subjects of considerable controversy (Nigro 1968). However, suspicion of collective bargaining has lessened, an important development that means public-sector unions can act as representatives of public sector workforces. To better understand public-sector unions in terms of union dynamics, employees' collective bargaining power, and legal environments for labor-management relationships that were influenced by New Public Management and New Public Service, comparison to private-sector unions proves helpful.

According to Farber (2005), four elements of union dynamics make private-sector unions and public-sector unions different: employment trends, the nature of the products, the role that unions can play, and the incentives employers face. First, private- and public-sector unions differ in terms of employment growth and job security. Even though employment is growing in both sectors, employers oppose unions more intensely in the private sector (Freeman 1988; Weiler 1983). Workers in the public sector can expect to remain in their jobs longer than workers in the private sector, although the current trend toward at-will employment has changed such expectations of job security. In this regard, the longer time horizon of public-sector employees compared to privatesector workers makes unions more attractive to employees in the public sector.

Second, differences in the nature of the products produced in the private and public 
sectors make unions in each sector different. Most significantly, the private sector faces substantial competition from goods and services produced in other countries because of globalization (Riccucci 2007; Farber 2005). Such a global economy makes the union strategy of "take wages out of competition" unfeasible, spurring private employee union decline. However, the public sector produces goods that are not tradable, such as public education and public safety. In this regard, although public-sector employers can use the threat of outsourcing to private-sector firms to win wage concessions, the public-sector union still draws some power from the unique characteristics of public goods and services (Farber 2005).

Third, while private-sector unions do not engage in the political process to determine the wages and benefits of members, the payoff to unions in the public sector of involving themselves in the political process can be substantial (Farber 2005). Through lobbying and working for the reelection of union-friendly officials who can give a direct payoff in favorable contract terms, public-sector unions can affect income for union members.

Finally, in contrast to private-sector employees who face stiff market discipline, public-sector employees are not necessarily accountable to market forces. Their discipline comes instead from the political process. For instance, the employers and unions in the public sector can work together through the political process to push through tax increases (Farber 2005).

\section{Public-Sector Unions’ Affiliation with Citizens}

As noted above, public-sector unions are primarily interested in public-sector employees' interests and therefore concentrate on political activities such as elections, program organization, and fighting privatization (Hurd and Pinnock 2004). For example, the unions struggle to prevent public policy that threatens employees' job security and organizations formed by employees (Reshef 2001). Another perspective views the important role of public-sector unions in determining policy as an interest group that seeks legislative change to maximize public employees' utility (Schwochau 1994). For instance, public-sector unions such as AFSCME have tried to protect against external and internal pressures and attacks on public employees and unions. As a result, AFSCME has succeeded in leading public employees to win collective bargaining rights, adopt merit-based job performance systems, increase public employees' pension plans, and attain wage increases (McEntee 2006).

However, public-sector unions have recently faced challenges from market-based ideology and public-service-oriented values (Hurd and Pinnock 2004). Due to increasingly difficult bargaining environments, public-sector unions engaged in collective 
bargaining do not necessarily represent only public employees' interests any more (Hurd and Kriesky 1985). Instead, their activity shows an increased affiliation with citizens. Citizens can be affected by the influence of public-sector unions on public policy and management through budgetary decisions at all levels of government (Hurd and Pinnock 2004). Although political activities may be aimed at maximizing the interests of public-sector unions, the resulting impacts on public policy can affect citizens substantially (Anderson and Delaney 1990), as can the results of collective bargaining agreements.

Since the major activities of public-sector unions, such as collective bargaining, are intertwined with politics and public budgeting, citizens will perceive positive or negative effects as taxpayers and voters (Freeman 1986). Therefore, the issues of labormanagement relations have direct impacts not on only public employees and organizations themselves at the micro level, but also on other important stakeholders like taxpaying and voting citizens at the macro level (Calo 2006). In addition, the decisions of public-sector unions can affect citizens in the community by generating support for or opposition to elected officials and by influencing career bureaucrats (Hurd 2003).

The impacts of public-sector unions on citizens are closely associated with the socio-cultural environment of a community (Masters 1962). One empirical study supporting unions' political action revealed that citizens identified with the policies of local public unions in 26 major Canadian municipalities (Anderson and Delaney 1990). This perspective is inconsistent with the traditional concept that political voting is a purely personal matter (Campbell, Converse, Miller, and Stokes 1964). Previous empirical research regarding the relationship between public-sector unions and citizens was presented by Hurd and Kriesky (1985) to investigate the International Association of Fire Fighters in the city of Dover, New Hampshire. According to the study, firefighters threatened by privatization tried to develop community awareness of and support for their position rather than bidding for the contract or undergoing collective bargaining. In this context, public-sector unions have more political impact on citizens as well as public-sector employees (Calo 2006).

\section{Public-Sector Unions in the Process of Privatization}

Union representation in the public-sector workforce and union affiliation with citizens become controversial issues in the context of privatization trends in the public sector. Because public organizations have recently faced financial pressures, most public programs and systems are under pressure to restructure public services through privatization (Hebdon 2006). According to economic and social policy perspectives, the privatization principle holds that the private sector, dependent on market forces, 
can provide citizens with more service at lower costs than the public sector (Dannin 1998). This trend has contributed to decreasing unionism in general and outspoken opposition to privatization (Hurd and Pinnok 2004). According to previous research regarding public-sector unions' role in the process of privatization (e.g., Bennett and DiLorenzo 1983; Ferris and Graddy 1986; Dubin and Navarro 1988; Chandler and Feuille 1991), unions have been depicted from two perspectives: as the reason for needing private service delivery and from an anti-privatization viewpoint.

Most research regarding the juncture between privatization and labor relations in the federal sector indicates that unions contributed to high costs and negatively influenced the decision to privatize because they were more interested in public employees' job security than in cost savings (Chandler and Feuille 1991; Lewis 1988). The opposition to privatization from public-sector unions generally is due to two reasons: the dissolution of the union and the job security of union members (Chandler 1994; Lewin 1986). Privatization has been found to wield disproportionate negative impacts on minorities and women due to concern over the effects of employee displacement (Hebdon 2006; Paul 1987). Additionally, some previous studies found that increasing adoption of atwill employment in public sector organizations can also negatively influence minorities and women, and, therefore, public-sector unions may oppose at-will employment (Wilson 2006). In this regard, public-sector unionism and privatization are essentially in conflict (Naff 1991).

The opposition to privatization from public-sector unions can be traced to rational choice, as explained earlier. Since unionization has declined where privatization has occurred, the anti-privatization stance is a rational response for public-sector unions. City sanitation unions did not support sanitation privatization because the difference between union and nonunion wages was lessened by increases in the threat of sanitation privatization (Chandler 1994).

Hoover and Peoples' 2003 study of the impact of unions on privatization used data from the Current Population Survey, which included outgoing rotation groups for each monthly file from 1983 to 1996 on refuse workers. They found that high union earnings for workers in the public sector are a source of labor cost savings in the refuse industry after privatization. Hebdon's 2006 study, which used data from 54 case studies of restructuring public services in towns and counties in upstate New York, found that privatization was likely to have significant deunionizing effects but might not have a clear impact on employee wages and benefits.

Public unions' activities regarding privatization merit consideration from a public policy perspective because the union's self-interest may well be incongruent with citizens' desire for cost savings. For example, privatization through contracting might lead to conflict between the political powers of taxpayers eager to save costs and pro- 
tection for unionized public employees' jobs (Chandler and Feuille 1991).

Nevertheless, public-sector unions' roles are very important during the process of privatization. As many scholars have argued (e.g., Bennett and Johnson 1979; Chandler 1994; Simmons 2002), public-sector unions are better able to protect employees from job displacement related to privatization. Also, unions can play an important role in protecting employee rights with regard to employee welfare (Simmons 2002). In this perspective, restructuring public-sector unions or fostering the capacity of publicsector unions may need to be considered. Table 2 reviews key studies of privatization and public-sector unions.

Table 2. Empirical Studies of Privatization and Public-Sector Unions

\begin{tabular}{|c|c|c|}
\hline Study & Data used & Findings \\
\hline $\begin{array}{l}\text { Bennett and } \\
\text { J ohnson } \\
\text { (1979) }\end{array}$ & $\begin{array}{l}\text { Data from garbage collection } \\
\text { privatization process between } \\
1983 \text { and } 1996\end{array}$ & $\begin{array}{l}\text { Unions functions to protect public employees: } \\
\text { Unions are better able to protect their members from } \\
\text { job displacement associated with privatization. }\end{array}$ \\
\hline $\begin{array}{l}\text { Hurd and } \\
\text { Kriesky } \\
\text { (1985) }\end{array}$ & $\begin{array}{l}\text { Case study of International } \\
\text { Association of Fire Fighters in } \\
\text { Dover, New Hampshire }\end{array}$ & $\begin{array}{l}\text { Union's new strategy in response to privatization: } \\
\text { The International Association of Fire Fighters selected } \\
\text { a community-based strategy instead of the collective } \\
\text { bargaining process when a privatization proposal was } \\
\text { presented. }\end{array}$ \\
\hline $\begin{array}{l}\text { Chandler and } \\
\text { Feuille } \\
\text { (1991) }\end{array}$ & $\begin{array}{l}\text { Data from } 1,256 \text { cities on the } \\
\text { union status of their sanitation } \\
\text { employees }\end{array}$ & $\begin{array}{l}\text { Unions' positive response to privatization: } \\
\text { Cities with unionized sanitation employees are less } \\
\text { likely to seriously consider the privatization of sanitation } \\
\text { service and less likely to implement privatization when } \\
\text { it is contemplated. Thus, privatization did not necessarily } \\
\text { lead to high unemployment. }\end{array}$ \\
\hline $\begin{array}{l}\text { Naff } \\
(1991)\end{array}$ & $\begin{array}{l}\text { Case study with interviews of } \\
\text { federal management officials } \\
\text { and representatives of the four } \\
\text { major unions representing } \\
\text { federal employees }\end{array}$ & $\begin{array}{l}\text { Cooperative labor-management relations during the } \\
\text { process of privatization: } \\
\text { Unions do not remain on the sidelines as management } \\
\text { makes a decision to privatize. }\end{array}$ \\
\hline $\begin{array}{l}\text { Chandler } \\
\text { (1994) }\end{array}$ & $\begin{array}{l}\text { Data on the union status of } \\
\text { sanitation employees in city } \\
\text { refuse collection for } 1973-1988\end{array}$ & $\begin{array}{l}\text { Unions function to protect public employees: } \\
\text { Increases in the threat of sanitation contracting reduce } \\
\text { sanitation employees' union-nonunion wage differential. }\end{array}$ \\
\hline $\begin{array}{l}\text { Simmons } \\
(2002)\end{array}$ & $\begin{array}{l}\text { Cases about American Federation } \\
\text { of State, County and M unicipal } \\
\text { Employees in the process of the } \\
\text { Temporary Assistance to Needy } \\
\text { Families program }\end{array}$ & $\begin{array}{l}\text { Unions function to protect public employees: } \\
\text { Unions such as AFSCM E have a distinct interest in } \\
\text { future welfare policy and programs and are involved } \\
\text { in the debate. }\end{array}$ \\
\hline
\end{tabular}




\begin{tabular}{l|l|l}
\hline \multicolumn{1}{c|}{ Study } & \multicolumn{1}{c}{ Data used } & \multicolumn{1}{c}{ Findings } \\
\hline $\begin{array}{l}\text { Hoover and } \\
\text { Peoples } \\
(2003)\end{array}$ & $\begin{array}{l}\text { Date from Current Population } \\
\text { Survey outgoing rotation groups } \\
\text { for each monthly file from 1983 } \\
\text { to } 1996 \text { on refuse w orkers }\end{array}$ & $\begin{array}{l}\text { Privatization's impact on unions: } \\
\text { High union earnings for workers in the public sector } \\
\text { are a source of labor cost savings in the refuse } \\
\text { industry after privatization of refuse collection. }\end{array}$ \\
\hline $\begin{array}{l}\text { Hebdon } \\
\text { (2006) }\end{array}$ & $\begin{array}{l}\text { 54 case studies of restructuring } \\
\text { public services in towns and } \\
\text { counties in upstate New York }\end{array}$ & $\begin{array}{l}\text { Privatization's impact on unions: } \\
\text { Privatization had significant deunionizing effects. } \\
\text { On the other hand, it had no clear impact on wages } \\
\text { and benefits. }\end{array}$ \\
\hline
\end{tabular}

\section{Labor-Management Relationships under Conditions of Privatization}

The tension between privatization and public-sector unions involves complex issues with no clear-cut answers. When public-sector unions focus on supporting and representing public employees, they will naturally be in strong opposition to privatization. As noted above, however, the activities of public-sector unions are closely affiliated with citizens in the community and society, and so they also have strong impacts on citizens. In this context, it is not easy to judge whether opposition to or support for privatization would be more beneficial for public employees and citizens together. Therefore, unions need to balance the interests of employees with the anticipated impact on managerial prerogatives and public policy (Malin 2002).

One of the most significant issues with respect to privatization is the labor-management relationship. Whether the effects of privatization are positive or negative depends on the extent to which unions and employers are involved in the process and how they participate in it. A balanced labor-management relationship is not easy to attain under conditions of privatization (Naff 1991). Nevertheless, most states have ruled that the contracting-out form of privatization is subject to mandatory bargaining because it affects public employees' conditions at work (Sauter 1988). Meanwhile, labor-management relationships in federal organizations are based on the federal labor relations law and an Office of Management and Budget directive.

The federal labor relations law, Title VII of the Civil Service Reform Act, not only gives management the authority to make decisions regarding contracting out, but requires federal agencies to bargain with public employees over matters that affect their working conditions (Naff 1991). The 1983 Office of Management and Budget directive Circular A-76 (GAO 1988) provided additional important legal guidance on privatization and urged public employees' participation in the process of contracting out.

Based on these two documents, most labor-management relationships have been 
resolved by the Federal Labor Relations Authority (FLRA) and the courts. For example, a previous legal case regarding privatization, IRS vFLRA, showed perspectives regarding labor-management bargaining over privatization. At first, the FLRA ruled the privatization proposal, and then the National Treasury Employees Union was negotiable with unions. However, the D.C. Circuit Court ruled that the FLRA decision might be incorrect (IRS v FLRA, 862 F. 2d 880, 1988).

When the Supreme Court ruled in April 1990 on whether the proposal would provide a means for unions to influence contracting-out decisions (Department of the Treasury, IRS v. FLRA, et al. 110 S. Ct. 1623 (1990)), it sided with the IRS rather than the FLRA. According to the majority opinion of the Court, "it is entirely up to the IRS whether it will comply at all with the Circular's requirements, except to the extent that such compliance is required by an 'applicable law"' (Naff 1991, 26). Therefore, management's decision to contract out is not negotiable between unions and managers.

However, the Supreme Court decision does not mean that unions are not allowed to participate in negotiating the process of privatization (Naff 1991). Two 1990 bills regarding unions' participation in the contracting-out process, H.R. 4015 (the Commercial Activities Contracting Procedures Act) and H.R. 4049 (the Efficiency in Government Act), also gave public-sector unions rules as to participation in privatization decisions.

Naff (1991) conducted a case study based on interviews with federal management officials and representatives of the four major unions representing federal employees. The study found that unions did participate in the process of privatization, and cooperative labor-management relations during this process were helpful for successful implementation of privatization. According to O'Leary (2010), on the other hand, broken labor-management relationships can lead to a hostile situation in the workplace. For instance, when an urban school district attempted to revamp its bus transportation contract, about 30 unionized bus drivers interrupted a school committee meeting on the issue. During such a conflict, cost-saving and improved school bus transportation service were not considered (O'Leary 2010). This case showed the importance of a trusting relationship between labor and management. Additionally, the case showed the need to reconsider the role of unions, since unions can be considered representatives of labor. Fostering a cooperative relationship between labor and management is necessary.

\section{DISCUSSION AND IMPLICATIONS}

This study has reviewed the historical and institutional backgrounds of unions by sector, internal and external trends regarding public-sector unions, union representa- 
tion in the public-sector workforce, union affiliation with citizens, and the relationship between privatization and public unions. Using these characteristics to reflect on the role of public-sector unions as the negotiators for public employees and as the promoters of political affiliation with citizens, the nature of labor-management relationships emerges as a key factor in determining the effectiveness of unions. Thus, two suggestions for better labor-management relationships follow.

\section{Foster Public-Sector Unions' Capacity}

According to Nigro (1968), the four important values in public-sector unionization are democracy, justice, pragmatism, and idealism. Democracy means the rights of the workers to participate in determination of management policies. Justice is about an end to paternalism, which allows management to judge the fairness of employee treatment. Pragmatism holds that policies and work results will improve under a partnership arrangement between labor and management. Idealism connects higher levels of public service to employees' constant pressure on management in that direction. If any of these values were neglected, the quality of service to the public would decline. These four important values need to be kept in mind while public-sector unions foster their capacity in challenging environments.

In striving to maintain these four values, public-sector unions can also develop practical strategies for dealing with management and politics. First, in terms of management, unions need to form strategic plans by carrying out formal self-evaluation, conducting the examination about environments, monitoring the union's progress in implementing new programs, and addressing strategic issues (Hurd 2003). Furthermore, to get public support for sustaining unionism in the public sector, union leaders need to improve their image among public employees, managers, and citizens (Mosca and Pressman 1995). Most importantly, leadership must be adept at anticipating and understanding changes in the external environment, such as rising health care costs, and must understand the needs of workers.

Second, public-sector unions' viability depends on their ability to persuade the public and political leaders that union activities are tied to vital public policy concerns that go beyond members' self-interest. Some potent political issues are: (1) supportive career opportunities for a diverse workforce; (2) organizational justice in the allocation of benefits, training, and opportunities for involvement in the process of employee policies; (3) workforce productivity; and (4) retirement and health care (Klingner 1993). Public-sector unions need to actively participate in the process of making alternative policies internally or externally on such issues. When public-sector unions become involved in issues that are associated not only with the welfare of employees 
but also with the success of organizations with values of democracy, justice, pragmatism, and idealism, their capacity can be increased.

\section{Foster Cooperative Labor-Management Relationships}

Dynamic changes in political and economic environments have resulted in a paradigm shift in public-sector unions (Calo 2006). For their survival, they need to be understood as a labor-management partnership (Nigro 1968). If the relationships between the union and the employer are adversarial and hostile, conflict becomes inevitable (Denholm 1998). Adversarial relationships do not foster positive outcomes for public employees and citizens. Public-sector unions and employers have made progress in building labor-management partnerships. The federal-level IRS and National Treasury Employees Union for several years have tried cooperative ventures to deal with incentive pay and quality improvement (Naff 1991).

Cooperative labor-management strategy becomes more critical when challenging environmental trends such as privatization threaten favorable collective bargaining outcomes (Chandler 1994). Most of all, labor-management relations can actually influence the decision to privatize. One empirical study (Chandler and Feuille 1994) indicated that cities with cooperative labor-management relations were less likely to implement privatization than non-union cities. However, cities with more adversarial labor-management relations were more likely to privatize services. Therefore, unions need to cope with the threat of privatization by agreeing to reorganization plans that make it possible to complete work more efficiently at the local level (Naff 1991). In addition, legislative and institutional devices should be established to encourage cooperation by unions and management in decision making.

With this regard, O'Leary (2010) argued that the establishment of a joint labormanagement committee that focuses on process improvement can be useful for solving labor-management issues. According to this author, such process improvement committees (PICs) emphasize improving organizational efficiencies, unlike traditional labor-management groups that usually dealt with employee safety or other contractrelated issues. Based on clear ground rules, both labor and management can pursue their own interests through mutual respect and authentic dialogue. To do that, O'Leary (2010) suggested that leaders from labor, management, and even elected political officials need to discuss what is needed for a labor-management PIC initiative by inviting an experienced facilitator who has knowledge about labor-management relationships.

Additionally, establishment of trust is required for successful PICs. O'Leary advised that writing the guidelines of the committee agreement is not including negative job impacts for employees. In an agreement that is based on trust, the goal of 
introducing better work processes to generate efficiencies, or providing alternatives to displaced workers, such as training and the opportunity to shift to other positions, needs to be clarified. By providing employees with opportunities to effectively participate in management without fear through PICs, cooperative and successful labormanagement relations can be created.

As the external environment presents growing challenges to union viability in the public sector, these recommendations will allow unions to maintain high affiliation with the public and maximize the outcomes of bargaining with management in Korea as well. In Korea, research on the roles of public-sector unions is rare since the perception is widespread that public-sector employees are working for the citizens and their ability to strike should be limited. As discussed above, however, public-sector unions play important roles related to the protection of employee rights and benefits in changing environments caused by privatization and the adoption of at-will employment. Additionally, labor-management relations can be improved through conducting appropriate roles for unions.

Future studies should examine the structure and roles of public-sector unions in Korea. The present study conducted a qualitative data analysis based on a review of previous literature, and therefore it had a limited ability to reveal the actual roles or influences of public-sector unions. In future research, collection and analysis of quantitative data about public-sector unions are needed.

\section{REFERENCES}

Anderson, J. C., and J. T. Delaney. 1990. The involvement of Canadian unions in political activities: An exploratory analysis. Journal of Labor Research 11 (4): 361-79.

Bennett, J. T., and T. J. DiLorenzo. 1983. Public employee unions, privatization, and the new federalism. Government Union Review 3:59-73.

Bennett, J. T., and M. H. Johnson. 1979. Public versus private provisions of collective goods and services: Garbage collection revisited. Public Choice 34:55-63.

Bennett, J. T., and J. E. Taylor. 2001. Labor unions: Victims of their political success? Journal of Labor Research 22 (2): 261-73.

Bent, A. E., and T. Z. Reeves. 1978. Collective bargaining in the public sector: Labormanagement relations and public policy. Menlo Park, CA: Benjamin/Cummings.

Boaz, D., and E. H. Crane. 2003. CATO handbook for Congress: Policy recommendation for the 108th Congress. Washington, DC: CATO Institute.

Calo, T. J. 2006. The psychological contract and the union contract: A paradigm shift 
in public sector employee relations. Public Personnel Management 35 (4): 33142.

Camp, P. M., and W. R. Lomax. 1968. Bilateralism and the merit principle. Public Administration Review 28 (2): 132-37.

Campbell, A., P. E. Converse, W. E. Miller, and D. E. Stokes. 1964. The American voter: An abridgement. New York: John Wiley and Sons.

Chandler, T. 1994. Sanitation privatization and sanitation employees' wages. Journal of Labor Research 15 (2): 137-53.

Chandler, T., and P. Feuille. 1991. Municipal unions and privatization. Public Administration Review 51 (1): 15-22.

Chandler, T., and P. Feuille. 1994. Cities, unions and the privatization of sanitation services. Journal of Labor Research 15 (1): 53-71.

Coggburn, J. D. 2000. The effect of deregulation on state government personnel administration. Review of Public Personnel Administration 20 (24): 24-40.

Coggburn, J. D. 2001. Personnel deregulation: Exploring differences in the American states. Journal of Public Administration Research and Theory 11(2): 223-44.

Dannin, E. J. 1998. Labor and employment law developments in privatization. Labor Law Journal 49 (2): 834-43.

Denholm, D. Y. 1998. The case against public sector unionism and collective bargaining. Government Union Review 18 (1): 31-52.

Department of Labor. 2007. Another tough year for unions. $\mathrm{ftp}: / / \mathrm{ftp}$. bls.gov/pub/news.release/union2.txt

Dubin, J. A., and P. Navarro. 1988. How markets for impure public goods organize: The case of household refuse collection. Journal of Law, Economics, and Organization 4:217-41.

Farber, H. S. 2005. Union membership in the United States: The divergence between the public and private sectors. Working Paper 53, Princeton University, Industrial Relations Section.

Ferris, J., and E. Graddy. 1986. Contracting out: For what? With whom? Public Administration Review 46:332-44.

Freeman, R. B. 1986. Unionism comes to the public sector. Journal of Economic Literature 24 (1): 41-86.

Freeman, R. B. 1988. Contraction and expansion: The divergence of private sector and public sector unionism in the United States. Journal of Economic Perspectives 2 (2): 63-88.

Freeman, R. B., and R. G. Valletta. 1988. The NBER public sector collective bargaining law data set. In When public sector employees unionize, ed. R. B. Freeman and C. Ichniowski. Chicago: University of Chicago Press. 
Frege, C. M. 1996. Union membership in post-socialist East Germany: Who participates in collective action. British Journal of Industrial Relations 34:387-413.

Gahan, P. 2007. The politics of partnership: The evolution of public sector industrial relations in Victoria. In Public sector employment in the twenty-first century, ed. M. Pittard. http://epress.anu.edu.au/public_sector/mobile_devices/ch08s02.html.

GAO (U.S. General Accounting Office). 1988. Federal productivity: DOD's experience in contracting out commercially available activities. GAO/GGD-89-6, 10-11. Washington, DC: General Accounting Office.

Guiler, J. K., and J. M. Shafritz. 2004. Dual personnel systems-organized labor and civil service: Side by side in the public service. Journal of Labor Research 25 (2): 199-209.

Hebdon, R. 2006. Contracting public services in New York State: Labor effects. Industrial Relations 61 (3): 513-31.

Hoover, G. A., and J. Peoples. 2003. Privatization of refuse removal and labor costs. Journal of Labor Research 24 (2): 293-305.

Hurd, R. W. 2003. In defense of public service. WorkingUSA 7 (1): $6 ? 26$.

Hurd, R., and J. Bunge. 2003. Unionization of professional and technical workers: The labor market and institutional transformation. In Emerging labor market institutions for the 21st century, ed. R. Freeman, J. Hirsh, and L. Mischel. Chicago: University of Chicago Press for the National Bureau of Economic Research.

Hurd, R., and J. K. Kriesky. 1985. You can fight City Hall: The Dover, N.H., IAFF defeat of privatized fire protection. Labor Study Journal 10 (2): $123 ? 38$.

Hurd, R. W., and S. Pinnock. 2004. Public-sector unions: Will they thrive or struggle to survive? Journal of Labor Research 25 (2): 211-21.

Kearney, R. C., and D. G. Carnevale. 2001. Labor relations in the public sector. Marcel Dekker.

Kellough, J. E., and C. S. Selden. 2003. The reinvention of public personnel administration: An analysis of the diffusion of personnel management reforms in the states. Public Administration Review 63 (2): 165 ?76.

Kelly, C. 1993. Group identification, intergroup perceptions and collective action. European Review of Social Psychology 4:59?83.

Kettl, D. F., and J. W. Fesler. 2005. The politics of the administrative process. 3rd ed. Washington, DC: CQ Press.

Klandermans, B. 1986. Psychology and trade union participation: Joining, acting, quitting. Journal of Occupational Psychology 59:189-204.

Klingner, D. E. 1993. Public sector collective bargaining: Is the glass half full, half empty, or broken? Review of Public Personnel Administration 3 (2): 19?28.

Kochan, T. A. 1979. How Americans view labor unions. Monthly Labor Review 
102:23-31.

Levitan, S. A., and A. B. Noden. 1983. Working for the sovereign: Employee relations in the federal government. Baltimore: Johns Hopkins University Press.

Levy, P. A. 1985. The unidimensional perspective of the Reagan labor board. Rutgers Law Journal 16:269-390.

Lewin, D. 1986. Public employee unionism in the 1980's: An analysis of transformation. In Unions in transition: Entering the second century, ed. S. M. Lipset, 241-64. San Francisco: Institute of Contemporary Studies.

Lewis, G. H. 1988. Union/nonunion wage gaps in the public sector. In When public sector workers unionize, ed. R. B. Freeman and C. Ichniowski, 169-93. Chicago: University of Chicago Press.

Lipset, S. M., and I. Katchanovski. 2001. The future of private sector unions in the U.S. Journal of Labor Research 22 (2): 229-44.

Malin, M. H. 2002. Public sector labor law doctrine and labor management cooperation. Industrial Relations Research Association.

Masters, N. A. 1962. The organized labor bureaucracy as a base of support for the democratic party. Law and Contemporary Problems 27:252-65.

McEntee, G. W. 2006. The new crisis of public service employment. Public Personnel Management 35 (4): 343-46.

Mosca, J. B., and S. Pressman. 1995. Unions in the 21st century. Public Personnel Management 24 (2): 159-66.

Naff, K. C. 1991. Labor-management relations and privatization: A federal perspective. Public Administration Review 51(1): 23-30.

Nigro, F. A. 1968. The implications for public administration. Public Administration Review 28 (2): 137-47.

Nigro, L. G., F. A. Nigro, and J. E. Kellough. 2007. The new public personnel administration. Thomson.

O'Leary, J. 2010. Labor pains: Repairing the management-union relationship. Governing (blog). http://www.governing.com/blogs/bfc/repairing-management-unionrelationship.html.

Olson, M. 1971. The logic of collective action: Public goods and the theory of groups. Cambridge, MA: Harvard University Press.

Paul, A. 1987. Privatization sparks vigorous but inconclusive debate at political science meeting. Chronicle of Higher Education 16: A5-A6.

Reeves, T. Z. 2005. The demise of public employee unionism? Pearson Longman.

Reshef, Y. 2001. The logic of labor quiescence. Journal of Labor Research 22 (3): 635-52.

Riccucci, N. M. 2006. Public personnel management: Current concerns, future chal- 
lenges. Pearson Longman.

Riccucci, N. M. 2007. The changing face of public employee unionism. Review of Public Personnel Administration 27(1): 71-78.

Sauter, R. W. 1988. Union view: Subcontracting the work of union members in the public sector. Labor Law Journal August: 489- 90.

Schwochau, S. 1994. The reasons for interest group tactics and public sector labor relations policy. Journal of Labor Research 15 (4): 331-54.

Simmons, L. 2002. Unions and welfare reform: Labor's stake in the ongoing struggle over the welfare state. Labor Studies Journal 27 (2): 65?83.

Spero, S. D. 1962. Collective bargaining in public employment. Public Administration Review 1(4): 1 ?5.

Sulzner, G. T. 1985. Public sector labor relations: Agent of change in American industrial relations? Review of Public Personnel Administration 2 (1): $70 ? 77$.

Summers, C. W. 1974. Public employee bargaining: A political perspective. Yale Law Journal 83: 1156-1200.

U.S. Bureau of Labor Statistics. 2007. Union Members Summary. http://www.bls.gov/home.htm

Weiler, P. C. 1983. Promises to keep: Securing workers' rights under the NLRA. Harvard Law Review 96:1769-1727.

Weiner, B. 1985. Spontaneous causal thinking. Psychological Bulletin 97: 74-84.

Wilson, G. 2006. The rise of at-will employment and racial inequality in the public sector. Review of Public Personnel Administration 26 (2): 178 ?87.

Zander, A. S. 1962. A union view of collective bargaining in the public service. Public Administration Review 1 (4): $5 ? 13.2$ 